Ulrich Kohler

\title{
Estimating the Potential Impact of Nonvoters on Outcomes of Parliamentary Elections in Proportional Systems with an Application to German National Elections from 1949 to 2005
}

I would like to thank Martin Ehlert, Thomas Gschwend, Jan Paul Heisig, John Scott Long, Eric Plutzer, and Bernhard Weßels for their comments and encouragement. This article, like every scientific contribution, rests on the shoulders of giants. In the case of this article, however, the giant has a name: Richard Rose. Without this fruitful and inspiring collaboration it would not have been possible to complete this paper. For that collaboration I am grateful.

November 2009

Order-No:

SP I $2009-206$

Research Area Education, Work, and Life Chances

Research Unit Inequality and Social Integration

http://www.wzb.eu/bal/usi

e-mail:kohler@wzb.eu 



\section{Abstract}

"If [voter] turnout was $100 \%$, would it affect the election result?" (Bernhagen and Marsh 2007) is a frequently asked research question. So far, the question has been primarily answered regarding the changes in the distribution of votes. This article extends the analysis to changes in the distribution of seats and government formation. It proposes a method that factors in apportionment methods, barring clauses, size of parliaments, leverage of nonvoters, closeness of election results, and individual characteristics of nonvoters. The method is then applied to German national elections from 1949 to 2005. The application shows that Germany's Social Democratic Party (SPD) would have gained from the counterfactual participation of nonvoters, although usually not enough to result in a government change. However by the 1994 and 2005 elections evidence shows that such a government change could have happened. 



\section{Contents}

\begin{tabular}{lll}
\hline & Introduction & 9
\end{tabular}

2 Modeling the potential impact of nonvoters 10

2.1 Target quantities . . . . . . . . . . . . . . . . . . 10

2.2 Estimation of the target quantities $\ldots \ldots \ldots \ldots$

$\begin{array}{lll}3 & \text { Application } & 16\end{array}$

3.1 Data . . . . . . . . . . . . . . . . . . . 16

3.2 Voting behavior of nonvoters . . . . . . . . . . . . . . 17

3.3 Representation gap $\ldots \ldots \ldots \ldots \ldots . \ldots \ldots 22$

3.4 Probability of government change . . . . . . . . . . . . . . . 25

\begin{tabular}{ll}
\hline References & $\mathbf{3 0}$
\end{tabular}

\begin{tabular}{ll}
\hline Appendix & 33
\end{tabular} 



\section{List of Figures}

$1 \quad$ Distribution of prediction variables by time $\ldots \ldots$. . . . . . . . . . . . . 19

$2 \quad$ Difference in vote proportions for parties between voters and nonvoters, with bootstrapped $95 \%$ confidence interval . . . . . . . . . . . . . 21

3 Change in seats in parliament from counterfactual participation of nonvoters $\left(\Delta S_{i}\right)$ with bootstrapped $95 \%$ confidence interval . . . . . . . . . . . 24

$4 \quad$ Gallagher index of disproportionality $(\Delta S)$ with bootstrapped $95 \%$ confi-

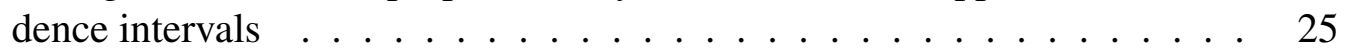

$5 \quad$ Bootstrapped distribution of seats from the 2005 election . . . . . . . . . 26

\section{List of Tables}

$1 \quad$ Particularities of German election laws . . . . . . . . . . . . . . . 23

$2 \quad$ Estimated probability of government change by election . . . . . . . . 27 



\section{Introduction}

"If turnout was $100 \%$, would it affect the election result?" This question is the prelude of an article by Bernhagen and Marsh (2007) that estimates the potential impact of nonvoters on election results by means of a multiple imputation technique. The present article extends this research question to the policy- relevant outcomes of election results and describes a method to estimate the impact of nonvoters on these outcomes. The proposed method is then used to estimate the potential impact of nonvoters on German national elections from 1949 to 2005.

The extension of the research question is as follows: "If turnout reached its maximum, would it affect (a) parliamentary representation and (b) the government formation in a parliamentary proportional system?" This reformulation differs from the above research question in two respects. First, it refers not to a counterfactual situation of $100 \%$ turnout but to the maximum level that could be achieved in a free and fair democratic election. Since even in the Soviet Union turnout has never been $100 \%$, this "maximum turnout" provides a more realistic basis for estimating the potential effects of increased turnout. Second, and more important, the reformulated research question does not deal with the distribution of votes but with two specific election outcomes: the composition of the parliament and the formation of the government.

It is a commonplace in political sociology that an election consists not just of counting votes (Powell 2000). The aim of proportional election laws is to have parliamentary elections guarantee that the composition of the parliament proportionally represents the distribution of interests in the society. In this respect, the "right" composition of the parliament is a goal in itself, and it would undermine the legitimacy of a political system if massive absenteeism of parts of the electorate led to ongoing underrepresentation of specific interests in the parliament. Analyzing whether, and how much, the distribution of seats in the parliament would have changed if nonvoters had participated in the election helps in answering normative questions about the legitimacy of the political system.

Apart from the normative question, the composition of the parliament has numerous highly practical policy consequences. In Germany, for example, the composition of the parliament determines the parties that are allowed to send members to parliamentary committees, and in what number, the length of the time-slots for speeches in plenary and committee meetings, and to some extent the funds available for the parliamentary groups. However, the most important policy outcome of the parliament composition is the formation of the government. In terms of key policy outcomes, no other consequence of the composition of the parliament comes even close to the decision of who governs, and who does not.

Thus far, researchers who have analyzed the potential impact of increased turnout have dealt solely with the effects on the distribution of votes; the results of these studies show that the potential impact of nonvoters is small (Lutz and Marsh 2007). However, the distribution of votes is only an input to the determination of the composition of the parliament, which in turn is an input to the process of government formation. Restricting the analysis to the distribution of votes therefore stops short of analyzing the real-world 
policy consequences of nonvoting. For a more realistic picture, it is necessary to do the final steps as well. The present analysis therefore departs from the work of authors such as Bernhagen and Marsh (2007), by factoring in the specific regulations of the election system, the closeness of the election, and the bargaining conditions of coalition formation. The first part of the article describes a method for doing this in a systematic way, and the second part illustrates the method with the case of German national elections since 1949.

\section{Modeling the potential impact of nonvoters}

\subsection{Target quantities}

The method proposed here estimates the potential impact of nonvoters on two target quantities. The first target quantity is based on the share of parliamentary seats held by each of the contending parties. When it comes to policy outcomes, the distribution of seats is more important than the distribution of votes, from which it usually differs due to various institutional mechanisms. One measure of the potential influence of nonvoters in terms of the distribution of seats is the extent to which the realized number of seats for a party differs from the number of seats for the same party under the counterfactual condition of maximum turnout. Denoting the realized number of seats for party $i$ as $S_{i}$, and the counterfactual number of seats for that party as $S_{i}^{*}$, this target quantity can be formally expressed as 1

$$
\Delta S_{i}=S_{i}-S_{i}^{*}
$$

In what follows, I refer to $\Delta S_{i}$ as the "representation gap" for party $i$. A summary statistic of the representation gap is attained following Bernhagen and Marsh's use of the Gallagher index of disproportionality (Gallagher 1991) by using

$$
\Delta S=\sum_{i=1}^{I}\left(\frac{S_{i}}{S}-\frac{S_{i}^{*}}{S}\right)^{2},
$$

where $S$ is the overall number of seats in the parliament at the time of the respective election. Equation (2) is the sum of the squared differences of the proportions of seats, whereas Bernhagen and Marsh (2007; 552) used the sum of the squared differences of the proportion of votes as their target quantity. Contrary to Bernhagen and Marsh's approach, a relatively strong difference in the vote proportion will not contribute to $\Delta S^{*}$ as long as the respective party remains below the barring clause set by the election law. At the same time, even tiny differences in the proportion of votes could make a huge difference in the representation gap, if these differences make one or several parties pass (or fall below) the barring clause.

The second target quantity is based upon the idea that the ultimate outcome of an election is the formation of a government. Therefore, the potential impact of nonvoters should be operationalized as the probability that the counterfactual participation of nonvoters in

1 All formulas are written in terms of the specific election $t$. For the sake of simplicity, I forgo subscripting the formulas with $t$. 
an election would lead to a different government that those actually formed after that election. Using the letter $O$ as the symbol for government outcome, a formalization of this target quantity is

$$
\operatorname{Pr} \Delta O)=\operatorname{Pr}\left(O \neq O^{*}\right),
$$

where $O$ denotes the realized government and $O^{*}$ denotes the government that would have been formed if nonvoters had participated in that election. In what follows I refer to $\operatorname{Pr}(\Delta O)$ as the probability of government change.

In a two-party parliamentary system the government is formed by the party with the most seats in the parliament. A change in government will therefore take place if the winning party becomes the runner-up under the counterfactual condition of maximum turnout. However, two-party systems are exceptional in parliamentary systems. In multiparty systems, elections almost invariably result in no party winning an absolute majority of seats in parliament. As a consequence, deciding who governs commonly requires bargaining over the terms of a coalition cabinet or a minority government; coming first in seats in parliament is not sufficient to guarantee a place in government (Kohler and Rose 2008: 8f; Laver and Shepsle 1996). In a multiparty system, the probability of government change can therefore be positive even if the counterfactual participation of nonvoters does not change the order of parties in the parliament. For a nonzero probability of government change, it is enough that nonvoters change the conditions of bargaining either to the extent that the realized government becomes algebraically impossible, or to the extent that impossible coalitions become algebraically feasible. The conditions under which either could occur differ slightly between the following four government types. These do not exhaust every conceivable outcome, but they do represent the large majority of cases in the election histories of advanced Western democracies.

Single-party government: a government formed by the party that won the absolute majority of seats in the parliament. If the real election leads to a single-party government, a substantial change in the bargaining conditions would occur if the winning party lost its absolute majority. Therefore, the impact of nonvoters on government formation is defined as the probability that the winning party loses its absolute majority, or, formally:

$$
\operatorname{Pr}(\Delta O \mid G=\text { Single-party government })=\operatorname{Pr}\left(S_{W}^{*}<\frac{1}{2} S\right),
$$

where the subscript $S_{W}^{*}$ denotes the counterfactual number of seats of the party that won the real election.

Winner's coalition: a coalition in which the winning party becomes the formateur of a coalition cabinet. If the real election leads to a winner's coalition, a substantial change of the bargaining conditions would occur if (a) a runner-up party outpaced the winning party, or (b) the realized coalition lost the absolute majority of seats in the parliament, or (c) the winner of the counterfactual election gained absolute majority on its own. Because these three counterfactual events are not disjunct, they 
cannot be easily combined into one single joint probability of government change. For the sake of simplicity, it is proposed to use the maximum value of the three independent probabilities of the above events as the probability of government change:

$$
\begin{aligned}
& \operatorname{Pr}(\Delta O \mid G=\text { Winner's coalition) } \\
& \quad=\max \left(\operatorname{Pr}\left(S_{R}^{*}>S_{W}^{*}\right), \operatorname{Pr}\left(S_{C}^{*}<\frac{1}{2} S\right), \operatorname{Pr}\left(S_{W^{*}}^{*}>\frac{1}{2} S\right)\right),
\end{aligned}
$$

where $S_{R}^{*}$ denotes the counterfactual number of seats of a "real-world" runner-up party, $S_{C}^{*}$ denotes the counterfactual number of seats for the realized coalition, and $S_{W^{*}}^{*}$ denotes the counterfactual number of seats for the winning party of the counterfactual election.

Consent coalition: a coalition in which the formateur is not the party with the most votes. In such a situation a change of the winning party in the counterfactual election will not necessarily lead to different bargaining conditions. This will be the case only if the realized coalition loses its majority of seats, or if one of the parties gains an absolute majority on its own. Therefore, the probability of government change becomes

$$
\begin{aligned}
& \operatorname{Pr}(\Delta O \mid G=\text { Consent coalition) } \\
& =\max \left(\operatorname{Pr}\left(S_{C}^{*}<\frac{1}{2} S\right), \operatorname{Pr}\left(S_{W^{*}}^{*}>\frac{1}{2} S\right)\right),
\end{aligned}
$$

which is a subset of equation (5) above.

Minority government: a government formed by parties or coalitions that do not have the absolute majority of seats. Minority governments appear when parties sense serious barriers against forming arithmetically possible coalitions. The government formation is much more a consequence of party decisions than of any of the other situations. The only counterfactual election result that definitely changes the bargaining conditions is when one party gains absolute majority on its own. Therefore, the probability of government change becomes

$$
\operatorname{Pr}(\Delta O \mid G=\text { Minority government })=\operatorname{Pr}\left(S_{W^{*}}^{*}>\frac{1}{2} S\right) .
$$

\subsection{Estimation of the target quantities}

Having defined how the potential influence of nonvoters should be conceptualized in principal we now turn to the task of estimating these counterfactual quantities.

\section{Representation gap}

To quantify the representation gap, it is necessary to estimate the absolute number of seats resulting from the counterfactual election. It is therefore necessary to estimate the 
distribution of votes of the counterfactual election, which in turn requires an estimation of maximum turnout and of the voting behavior of nonvoters. Once the counterfactual distribution of votes is known, it can be used as an input to the apportionment method, which leads to a distribution of seats in the parliament. The following works backward from the estimation of seats to the voting behavior of nonvoters.

The estimated absolute number of seats for party $i$ is

$$
\widehat{S}_{i}^{*}=A\left(\widehat{\mathbf{V}^{*}}\right)_{i}
$$

where $A(x)$ is the apportionment method. Typically, $A(x)$ is the Hamilton method, the Jefferson method, or the Webster method ${ }^{2}$ The input to the apportionment method is $\widehat{\mathbf{V}}$, which denotes the vector of estimated absolute numbers of votes for all parties that passed the barring clause, i.e.,

$$
\widehat{\mathbf{V}^{*}}=\left(\begin{array}{lllll}
\widehat{V}^{*} & \ldots & \widehat{V}^{*} & \ldots & \widehat{V}^{*} I
\end{array}\right) \mid \frac{\widehat{V}^{*}}{\widehat{V}^{*}}>H
$$

with $\widehat{V}^{*}$ being the estimated absolute number of votes for party $i$ in the counterfactual election. $\widehat{V^{*}}$ is the estimated absolute number of valid votes in the counterfactual election, which is $\sum_{i=1}^{K} \widehat{V^{*}}$, i.e., the sum of the estimated number of votes for all $K$ parties that participated in the real election. $H$ is the hurdle posed by the barring clause.

Hence, values for $\widehat{V}_{i}^{*}$ are needed. $\widehat{V}^{*}{ }_{i}$ can be expressed as the sum of the realized valid votes for party $i$ and the estimated additional votes for that party from the nonvoters, i.e.,

$$
{\widehat{V^{*}}}_{i}=V_{i}^{\text {Voter }}+{\widehat{V^{*}}}_{i}^{\text {Non-voter }} .
$$

The term $V_{i}^{\text {Voter }}$ in equation $(10)$ is known from official publications of the electoral authorities. An estimate must be obtained for $\widehat{V}^{*}{ }_{i}^{\text {Non-voter }}$, the absolute number of nonvoter votes for party $i$. To arrive at the estimation of $\widehat{V}_{i}^{*}$ Non-voter , assume for a moment that for each individual nonvoter the probability of voting for party $i$ were known from somewhere; let me denote this probability with $\widehat{\operatorname{Pr}}\left(y^{*}=i\right)^{\text {Non-voter }}$. Now the estimation of additional votes from the nonvoters for party $i$ is straightforward:

$$
{\widehat{V^{*}}}_{i}^{\text {Non-voter }}=\widehat{\widehat{\operatorname{Pr}}}\left(y^{*}=i\right)^{\text {Non-voter }} \times E \times \widehat{L}
$$

with $\widehat{\widehat{P r}}\left(y^{*}=i\right)^{\text {Non-voter }}$ being the average of the estimated probability of voting by the nonvoters for party $i, E$ being the size of the electorate, and $\widehat{L}$ being the leverage, i.e., the proportion of the electorate that might additionally participate in the election. Algebraically, $\widehat{L}$ is the difference between the (estimated) maximum turnout and the observed turnout of valid votes, i.e.,

$$
\widehat{L}=\widehat{T}^{\mathrm{Max}}-\frac{V}{E}
$$

2 The Hamilton method is also known as the largest remainder method or Hare/Niemeyer method. The Jefferson method is mathematically equivalent to the D'Hondt method, the Hagenbach-Bischoff method, and the Bader-Ofer method. Finally, the Webster method is also known as the Sainte-Laguë method. 
The sole unknown quantity in equation $(12)$ is the figure for maximum turnout. The theoretical limit of maximum turnout is $100 \%$, but this limit cannot be reached in real-world elections for many reasons (cf. Kohler and Rose 2008: 9-12). I do not set up an estimation strategy for maximum turnout in a specific election here-this is left open for the application in section 3. As a rule, one should generally expect maximum turnout to be higher if the time lag between the compilation of the electoral register and the elections is short, if the election laws allow postal voting, and if the ballot paper is simply designed. To give some quantities for maximum turnout: Kohler and Rose (2008) have used the average of valid turnout in the most recent parliamentary elections in European countries which strongly enforce their compulsory voting law--Belgium, Luxembourg, and Cyprus; this average turned out to be $85 \%$. In Australia, "the country with the oldest and probably the most efficient system of compulsory voting" (Mackerras and McAllister 1999), the valid turnout of the parliamentary election on November 24, 2007, was 91\%.3

Let us now turn to the estimation of $\operatorname{Pr}\left(y^{*}=i\right)^{\text {Non-voter }}$, the nonvoters' probability of voting for party $i$, which can be estimated only by making plausible assumptions. Here I highlight the minimum assumptions to be made and propose a general strategy to estimate that quantity on the basis of those assumptions. An example of how the estimation could be performed with real data is introduced in section 3 .

The most crucial assumption to be made is a model for voting behavior that is valid for voters and nonvoters. Think of this model as some variant of the Michigan model of voting behavior (Campbell et al. 1954, 1960; Miller and Shanks 1996), as some variant of the economic theory of voting behavior (Downs 1957; Fiorina 1981), or as some variant of the interpersonal influence theory in the tradition of Lazarsfeld et al. (1948), Berelson et al. (1954), or Huckfeldt and Sprague (1995). The fundamental commonality of all these models is that individual voting behavior is a consequence of a weighted combination of individual and contextual characteristics at the time of an election and some uncertainty; formally,

$$
\operatorname{Pr}(y=i)=f\left(\mathbf{x}, \mathbf{b}_{i}, \varepsilon_{i}\right)
$$

with $\mathbf{x}$ being a vector of characteristics, and $\mathbf{b}_{i}$ being a vector of parameters that link the characteristics to the probability of voting for party $i$. $\varepsilon_{i}$ is a reminder for uncertainty. Note that the model at this stage is not very restrictive. It determines neither any of the characteristics in $\mathbf{x}$ nor a functional form between the probability of voting for party $i$ and the characteristics in $\mathbf{x}$, nor does it assume that all of the characteristics equally influence the probability of voting for parties. The only assumption here is that the model applies to both voters and nonvoters. Without this assumption, estimation of the probability of voting for party $i$ of a specific nonvoter would be impossible. If the assumption is made, the lessons learned from studying voters can be used for predicting the voting behavior of nonvoters as follows:

$$
\widehat{\operatorname{Pr}}\left(y^{*}=i\right)=f\left(\mathbf{x}^{\text {Non- voter }}, \widehat{\mathbf{b}}_{i}^{\text {Voter }}\right)
$$

3 According to the Australian Government and Politics Database on http://elections. uwa.edu. $\mathrm{au} /$ the size of the registered electorate was 13,645,073, and the number of valid votes was 12,419,863. 
In other words, one estimates $\mathbf{b}_{i}$ for the characteristics $\mathbf{x}$ of the voters, and then replaces the values for $\mathbf{x}$ by the values of the nonvoters. Essentially, it is said that a nonvoter who has the same pattern as a voter on any of the characteristics that influence voting behavior would have the same probability to vote for any party as this voter. Clearly, this strategy is not new. Special cases of equation (14) are used in virtually any estimation of the counterfactual voting behavior of nonvoters.

After having made the crucial assumption of equation (13), there is some freedom of choice about the characteristics to include in $\mathbf{x}$, about the estimation technique for the parameters $\mathbf{b}_{i}$, and about the function that links the parameters and characteristics with $\operatorname{Pr}(y=i)$. Obviously, one ought to use characteristics that strongly predict voting behavior. One should also apply an estimation technique for the parameters $\mathbf{b}_{i}$ that leads to good estimates, and one should choose for $f(x)$ a function that does not lead to nonsensical estimates of $\widehat{\operatorname{Pr}}\left(y^{*}=i\right)$. However, all this is limited by the availability of data. It follows from equation (14) that the characteristics used for $\mathbf{x}$ must have been observed for both voters and nonvoters. One might be tempted to use information on voting intention in pre-election surveys to estimate $\mathbf{b}_{i}$, but these estimated parameters would be useless for the prediction of nonvoters' behavior, as long as these questions were posed to voters only. Because data availability is so crucial for the estimation of $\operatorname{Pr}\left(y^{*}=i\right)$, further specification is transferred to the application.

Here, the general outline of the model for estimating the representation gap ends. So far the discussion shows that the estimation of the representation gap requires only two quantities: maximum turnout and nonvoters' counterfactual probability of voting for party $i$. As soon as both quantities are estimated, the other steps are deterministic; one just needs the required information. The formulas show which information is needed in addition to the estimated quantities: the apportionment method $A(x)$ (which also requires information about the number of seats to be distributed), the absolute number of votes for all parties in the real election $\left(V_{i}^{\text {Voter }}\right)$, the size of the barring clause $(H)$, and the size of the electorate $(E)$. All these quantities are readily available for most if not all parliamentary elections.

\section{Probability of government change}

Equations (4)-(7) of subsection 2.1 can be formally concatenated to one single equation which states that the probability of government change depends on the probability that the counterfactual number of seats $\left(S^{*}\right)$ of a specific party or coalition $(P)$ is higher than a threshold value $\tau$, whereby the party or coalition and the threshold value are set according to the realized government type $G$ :

$$
\operatorname{Pr}\left(\Delta O_{G}\right)=\operatorname{Pr}\left(S_{P \mid G}^{*}>\tau_{G}\right)
$$

The previous section has outlined an estimation strategy for $S_{i}^{*}$ such that $S_{i}^{*}={\widehat{S^{*}}}_{i}+u_{i}$, where $u_{i}$ reflects the uncertainty originating from the estimation of nonvoters' counterfac- 
tual probability of voting for party $i .4$ Inserting $\widehat{S}^{*}{ }_{i}+u_{i}$ into equation 15 leads to

$$
\operatorname{Pr}\left(\Delta O_{G}\right)=\operatorname{Pr}\left(\left({\widehat{S^{*}}}_{P \mid G}+u_{P \mid G}\right)>\tau_{G}\right),
$$

which can be algebraically transformed to

$$
\operatorname{Pr}\left(\Delta O_{G}\right)=\operatorname{Pr}\left(u_{P \mid G}>\left(\tau_{G}-{\widehat{S^{*}}}_{P \mid G}\right)\right),
$$

and, assuming that the error term is symmetric, to

$$
\operatorname{Pr}\left(\Delta O_{G}\right)=\operatorname{Pr}\left(u_{P \mid G} \leq\left({\widehat{S^{*}}}_{P \mid G}-\tau_{G}\right)\right) \quad .
$$

This equation shows that the probability of government change depends on the threshold value, the estimated number of seats for party $P$, and the distribution of the error, $u$. Generally, the searched probability is given by the integral of the probability density function of the error $u$ :

$$
\operatorname{Pr}\left(\Delta O_{G}\right)=\int_{-\infty}^{\widehat{S^{*}} P_{G}-\tau_{G}} \operatorname{pdf}(u) d u
$$

To estimate this, one needs the estimation of $\widehat{S}^{*}$ i outlined in the previous section and an assumption about the distribution of the error term. However, as that error term is itself a function of the assumptions about the error in the estimation $\operatorname{Pr}\left(y^{*}=i\right)$, no additional assumptions have to be made for the estimation of $\operatorname{Pr}\left(\Delta O_{G}\right)$. It is only necessary to collect the information about parliament size, the name of the winning party, and the type of governing coalition that resulted from the real election.

\section{Application}

The method described earlier is now applied to all German national elections from 1949 to 2005. The major task of this application is the illustration of the method, so that the interpretation of the results is limited to the description of the decisions that are necessary when dealing with real empirical data. To further support the traceability of the presentation, the name of the Stata do-file that created a result is printed below each figure or table and made publicly available on the Internet: ${ }^{5}$

\subsection{Data}

A data set about German elections has been compiled; it contains the following institutional data for each German election since 1949:6

4 The reminder for uncertainty here is not equal to $\varepsilon_{i}$ of equation (13), because that term undergoes the transformations of the apportionment method as well. It is therefore denoted with a different symbol, although formally $u_{i}=f\left(\varepsilon_{i}\right)$.

5 See http://www.wzb.eu/ kohler/publications/

6 Stata do-file: crelections. do. Note that this do- file also creates the data for all state elections. 
- the size of the electorate, the absolute number of nonvoters, and the absolute numbers of second votes ${ }^{7}$ for all parties acquiring at least one vote (Statistisches Bundesamt 2005):8

- the absolute number of seats that each party is entitled to 99 on the basis of the election results (Statistisches Bundesamt 2005);

- the apportionment method, which changed from the Jefferson method to the Hamilton method in 1987;

- the barring clause, which has been 5\% since the beginning of the observation period, but which was applied separately by states in the election of 1949, and separately for eastern and western Germany in 1990; moreover, since 1953 parties of specific ethnic minorities are exempt from the barring clause;

- the names of the parties that formed a coalition cabinet ${ }^{10}$ and the government type (i.e., whether it was a single-party government, a winner's coalition, a consent coalition, or a minority government); so far, German governments have always been formed through either a winner's coalition or a consent coalition.

In addition to the institutional data on elections, data from the German National Election Studies 1994-2002 ${ }^{11}$ provided by the data archive of the Leibniz Institute for the Social Sciences (GESIS) have been used for estimating the parameters $\mathbf{b}$ of equation (13). The German National Election Studies is a collection of survey data sets on German federal elections. The collection contains data from both pre-election and post-election surveys. Not all data sets of the collection were suitable for the present analysis. As a rule, data from post-election surveys or from pre- election surveys very close to the election day were preferred. The list of all studies used is in the appendix.

For the German federal election of 2005, data from the last round of the German branch of the Comparative Study of Election Systems $(\mathrm{CSES}){ }^{12}$ have been used.

\subsection{Voting behavior of nonvoters}

A crucial step in the estimation of the representation gap and the probability of government change is the prediction of the counterfactual election behavior of nonvoters. As

7 German election law gives each voter two votes. The first vote is for a candidate in a constituency, the second vote is for a party list. The composition of parties in the parliament is decided (almost) exclusively by the distribution of the second votes, and for this reason these votes have been used.

8 The source lists the respective numbers for all elections from 1949 to 2002 . The results for the 2005 election have been taken from the web page of the Bundeswahlleiter (http://www. bundeswahlleiter.de/de/bundestagswahlen/BTW_BUND_05/downloads/).

9 The real number of seats can differ due to deputies moving from one party to another.

10 See http://de.wikipedia.org/wiki/Liste_der_deutschen_Bundesregierungen

11 For a description of the German National Election Studies see http://www.gesis.org/en/ services/data/survey-data/election-studies/german-federal-elections/

12 See http://www.umich.edu/ cses/ 
discussed in subsection 2.2, that estimation should be based on variables that are known to be strongly connected with voting behavior and that are observed for voters and nonvoters. If we follow standard theories of voting behavior, obvious candidates are variables such as partisanship, issue orientation, candidate orientation, and political ideologies. Unfortunately, such variables usually are not available in the surveys for the elections at the beginning of the observation period.

An alternative approach to estimating the counterfactual voting behavior of nonvoters is based on the theory of the politicized social structure. In a nutshell, this theory proposes that political parties have been formed by cleavages between major social groups, and that the parties have formed stable coalitions with the social group that they represent (Lipset 1960; Lipset and Rokkan 1967; Linz 1967; Pappi 1976, 2002). One implication of this theory is that political behavior is largely structured by social groups. Despite the debate on the possibly decreasing influence of social groups on voting behavior, there is little doubt that there has been a politicized social structure for several of the decades of the observation period, particularly in Germany. There is also evidence that the decrease, if any, has been less pronounced in Germany than in other countries (Pappi 1986). According to Pappi and Shikano (2002), voter intentions derived from the politicized social structure can be regarded as an operationalization of the normal vote, i.e., the hypothetical election result based on long-term or middle-term influences. Insofar as the following estimations of nonvoters' counterfactual voting behavior are by and large based on social structural variables, they reflect to a large extent nonvoters' long-term voting predispositions.

The basic assumption behind estimating nonvoters' political behavior is that they behave like voters who have the same social structural characteristics. One objection against this strategy points to the well-established finding that German ${ }^{13}$ nonvoters are less interested in politics than are voters (Steinbrecher et al. 2007: 240-248), and that they also have a lower degree of party identification (Steinbrecher et al. 2007; 218-228). These results are problematic insofar as the underlying action theory of the politicized social structure requires that actors have substantial knowledge about which party represents what interests. Obviously, these assumptions seem less justifiable for persons with low levels of political interest than for persons with high levels of political interest. Any prediction of nonvoters' counterfactual behavior should therefore take into account the possibility that the social structural position might play less of a role for persons with low levels of political interest. The prediction model below does this by using all two-way interactions between the social structural variables and political interest. This approach has the effect of muting class distinctions for persons with low levels of political interest. If the interaction is strong, it could help explain why studies show that increased turnout does not automatically help the working-class parties (Fisher 2007).

Nonvoters' counterfactual voting behavior was predicted for each national election separately by performing the following steps:

1. Estimation of $\widehat{\mathbf{b}}_{i}^{\text {Voter }}$ of equation (14). Based on data on voters only, a multinomial logistic regression model (Long 1997) for reported voting behavior was estimated

13 These findings have been established for other countries as well (Powell 1986). However, the effect seems to be particularly strong in Germany (Oppenhuis 1995: 59). 

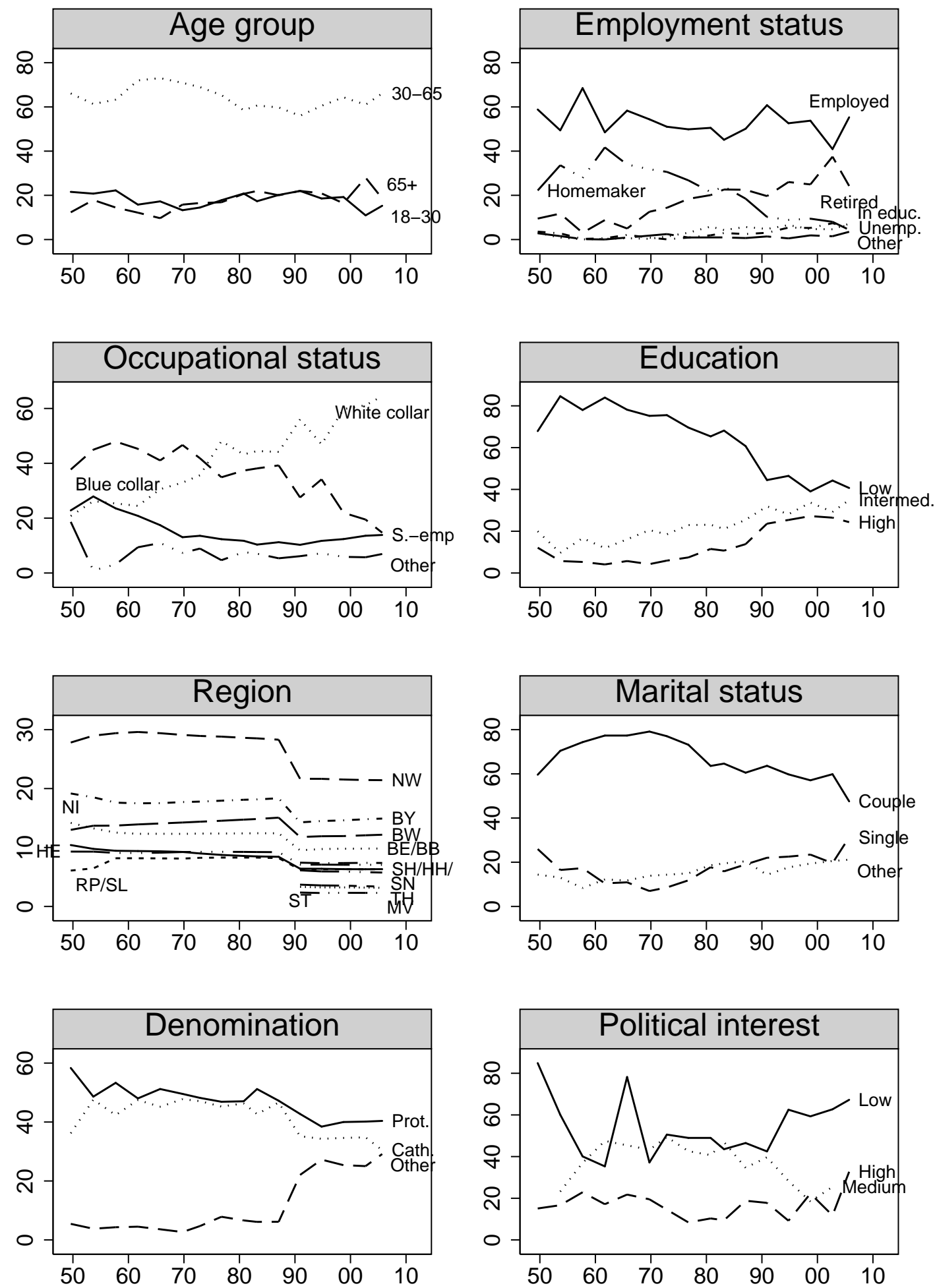

Figure 1: Distribution of prediction variables by time 
for each survey separately. The independent variables were a list of social structural variables, political interest, and all two-way interactions between political interest and the social structural variables. Due to data limitations, the dependent variable of that regression distinguished only between the two leading parties - the CDU/CSU (Christian Democratic Union/Christian Social Union) and the SPD (Social Democratic Party) — and all other parties; the counterfactual vote proportion of the smaller parties was estimated in step 4 .

The social structural characteristics in the regression model were age, employment status, occupational status of the main earner, education, region, marital status, and denomination. Political interest is the self-assessed political interest or, if a selfassessment is not available, an additive index of interests in political topics in the mass media. $\sqrt{14}$ Figure 1 shows the weighted proportions ${ }^{15}$ of the regression model's independent variables, which are based on the observations included in the regression model.

2. The vector of coefficients estimated in step 1 was used to predict the probabilities among nonvoters of voting CDU/CSU, SPD, or for the other parties. This amounts to applying equation (14) for $i=\mathrm{CDU} / \mathrm{CSU}, \mathrm{SPD}$, and the other parties.

3. The averages of the individual probabilities of all nonvoters were taken to get nonvoters' average probability of voting for party $i$, i.e., $\widehat{\operatorname{Pr}}(y *=i)$ of equation 11 .

4. Finally, the vote proportions of the parties from the "Other" category were created. For the sake of simplicity it was assumed that the nonvoters' votes for other parties are distributed proportional to the observed proportion of votes for each of these other parties. Hence, the bigger parties in the "Other" category gain more of these votes than do the smaller ones.

Figure 2 shows the results of these four steps. It displays the difference in vote proportions between voters and nonvoters for the five most important German parties. Negative values for a given party indicate that this party would have lost if nonvoters had participated in the election. The figure illustrates that nonvoters tend to be more in favor of the SPD and less in favor of the CDU/CSU than are voters. In this sense, the SPD would have gained if nonvoters had participated. However, it also turns out that the advantage for the SPD is not constant across elections, and that other parties sometimes gain and sometimes lose through the participation of nonvoters. Moreover, there is no obvious pattern in the ups and downs of nonvoters' support for parties.

14 The creation of the various variables is documented in the Stata do-file crbtwsvy . do.

15 Weighting was necessary due to the overproportional sampling probabilities of citizens in eastern Germany in many surveys. The weighting variable is the reciprocal of the sampling probability in each state, i.e., $\left(\frac{n_{\text {state }}}{E_{\text {state }}}\right)^{-1}$, with $n_{\text {state }}$ being the number of observations in each state and $E_{\text {state }}$ being the size of the electorate in each state. As $n_{\text {state }} \times \frac{E_{\text {state }}}{n_{\text {state }}}=E_{\text {state }}$, the distribution of states in figure 1 is merely the relative size of the electorates. 


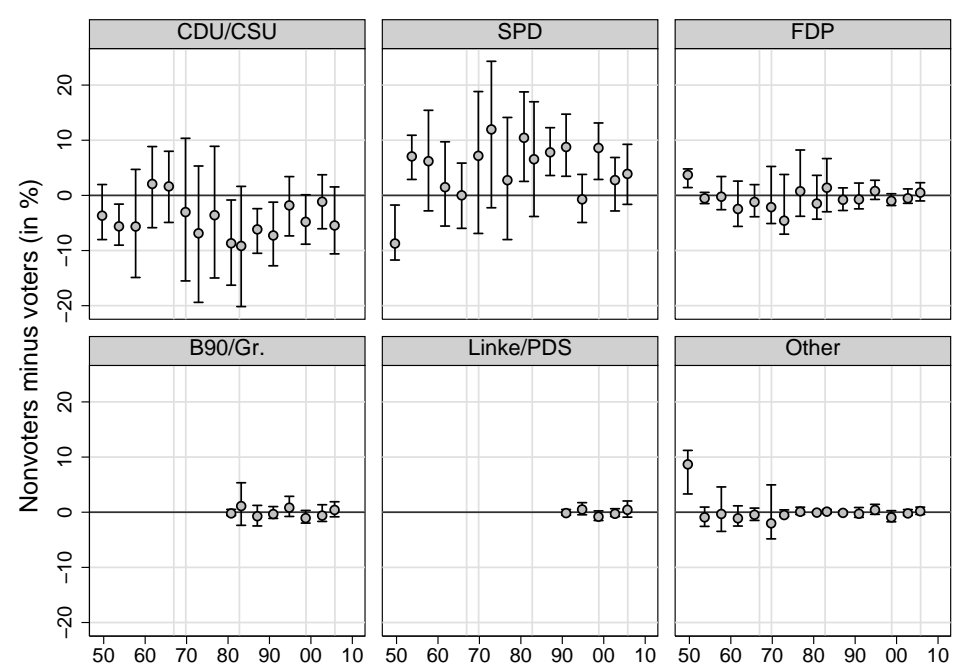

Figure 2: Difference in vote proportions for parties between voters and nonvoters, with bootstrapped $95 \%$ confidence interval

Do-file: anmpred2.do, grbehavdiff.do

The vertical capped lines in the figure show the 95\% confidence intervals around the plotted statistic. These confidence intervals have been estimated using a bootstrap method (Efron and Tibshirani 1993). The correct interpretation of these intervals is that $95 \%$ of the bootstrapped, average predicted probabilities of nonvoters differ between the upper and lower value of the vertical lines from that of voters. Hence, the longer the vertical lines, the more uncertain is the estimate of the difference in the voting behavior between voters and nonvoters. Particularly for the SPD and the CDU/CSU, for which the model predicts probabilities near 50\%, the uncertainty of prediction is substantial-but realistic given the amount of data. Judged by this bootstrapped confidence interval, the estimated vote proportion for the SPD among the nonvoters is between 45 and 71\% in 1972, which is between 1 percentage point below and 25 percentage points above the real election result. Later, when making projections about the probability of government change, we take advantage of the uncertainty of these estimates (subsection 3.4).

The general finding that the SPD would by and large profit from the participation of nonvoters mirrors the finding that nonvoters are typically from the lower-educated working class. However, a large difference between the observed voting behavior of voters and the estimated counterfactual behavior of nonvoters does not necessarily mean that the SPD would receive a higher proportion of seats in the German Bundestag. At the very minimum, this also depends on the proportion of nonvoters and on the question of whether some of the smaller parties pass or fail the barring clause in the counterfactual election. These questions will be dealt with in the next section.

The prediction model for the counterfactual voting behavior of nonvoters is a crucial step in the estimation of the impact of nonvoters on election outcomes, and it is absolutely 
necessary to carefully examine the validity of these results. At the very least, the models should have a reasonably good fit, and their coefficients should not contradict known empirical relationships. These characteristics have been confirmed for the present prediction models; the results of that analysis are available from the author.

\subsection{Representation gap}

After having established an estimation of nonvoters' probabilities of voting for a specific party, the next step is to produce the counterfactual distribution of seats. This step involves an application of the formulas (11), (10), (9), and (8) in turn. The major difficulty is to come up with an estimation of $\bar{L}$, the proportion of the electorate that might additionally participate in the election. The estimation of this quantity requires an estimation of $\widehat{T}^{\mathrm{Max}}$, the turnout that could maximally be achieved. Kohler and Rose (2008) set $\widehat{T}^{\text {Max }}$ to the average valid turnout of countries with strong enforcement of compulsory voting, which was $86.9 \%$. In Germany, however, the realized valid turnout was even higher than this theoretical maximum for several elections. Therefore, the highest realized valid turnout, which was $90.4 \%$ in 1972,16 is proposed here as a rough estimate of maximum turnout.

In the application of the apportionment rule, some particularities of German election laws have to be considered. Table 1 lists these particularities and the solutions found for producing the counterfactual seat distribution. To apply the apportionment methods, the Stata program _gprseats. ado has been developed and made publicly available on the Statistical Software Components archive at Boston College. Feeding the vector of absolute numbers of votes for each party into this program results in the counterfactual number of seats for each party at each election. Figure 3 shows these results in comparison to the realized number of seats. As in figure 2 , dots are used to indicate the point estimates, and vertical capped lines are used to indicate the $95 \%$ confidence intervals.

Figure 3 reveals that the participation of nonvoters would have resulted in minor to moderate changes in the number of seats. The highest expected difference is observed for 1990, with a loss of nine seats for the CDU/CSU and a gain of nine seats for the SPD. This results in a gross advantage of 18 seats for the SPD, which is still fairly small given that the CDU/CSU won 319 and the SPD 239 seats in that election. Subsection 3.4 will deal in more detail with the probability of government change given the differences in the number of seats.

Most other displacements remain below five seats, and in the majority of cases it is just one seat, more or less. Most of the effects of nonvoters' participation work in favor of the SPD, and in general the expected changes have become more accentuated since German reunification in 1990. However, it should be noted that the size of the German parliament has increased from 469 to 656 since that time, so that the same change in the absolute number of seats has become less important.

A notable exception to the rule that the SPD would have gained most from nonvoters is the first election after the Second World War, when other parties would have profited most from the nonvoters. The 1949 election has been viewed as the last election of the Weimar

16 Officially reported turnout in 1972 was $91.1 \%$, and the proportion of invalid votes was $0.73 \%$. 


\begin{tabular}{|c|c|}
\hline Problem & Solution \\
\hline $\begin{array}{l}\text { Barring clause was applied separately in each } \\
\text { German state in } 1949 .\end{array}$ & $\begin{array}{l}\text { Nationwide application of the barring clause for } \\
\text { the real world and for the counterfactual election. } \\
\text { Hence, the counterfactual distribution of seats is } \\
\text { compared with a distribution of seats that would } \\
\text { have resulted from the realized election result if } \\
\text { the barring clause had been applied nationwide. }\end{array}$ \\
\hline $\begin{array}{l}\text { Barring clause was applied separately for western } \\
\text { and eastern Germany in } 1990 \text {. The PDS, the suc- } \\
\text { cessor party of the East German communist party, } \\
\text { entered the parliament through this exclusionary } \\
\text { rule. }\end{array}$ & $\begin{array}{l}\text { PDS votes were used in the apportionment } \\
\text { method regardless of their counterfactual nation- } \\
\text { wide election result in } 1990 \text {. }\end{array}$ \\
\hline $\begin{array}{l}\text { According to the so-called Grundmandate rule, } \\
\text { parties winning at least three (until 1953: one) } \\
\text { direct mandates }{ }^{a} \text { participate in the apportionment } \\
\text { of seats on the basis of second votes regardless of } \\
\text { the barring clause. }\end{array}$ & $\begin{array}{l}\text { Parties that entered parliament through the } \\
\text { Grundmandate rule participate in the apportion- } \\
\text { ment regardless of their counterfactual election } \\
\text { result. }\end{array}$ \\
\hline
\end{tabular}

\footnotetext{
German election law allows so-called Überhang seats, which are seats that a party could win in

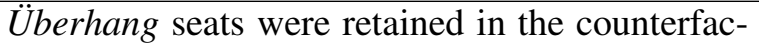
addition to the seats determined through the aptual seat distribution. portionment method.

${ }^{a}$ In Germany, voters have two votes. The important vote is the second vote, which determines the distribution of seats. However, a candidate who wins the relative majority of votes in a specific constituency enters parliament regardless of whether his or her party wins seats on the basis of the second vote; this is the so-called direct mandate.
}

Table 1: Particularities of German election laws 


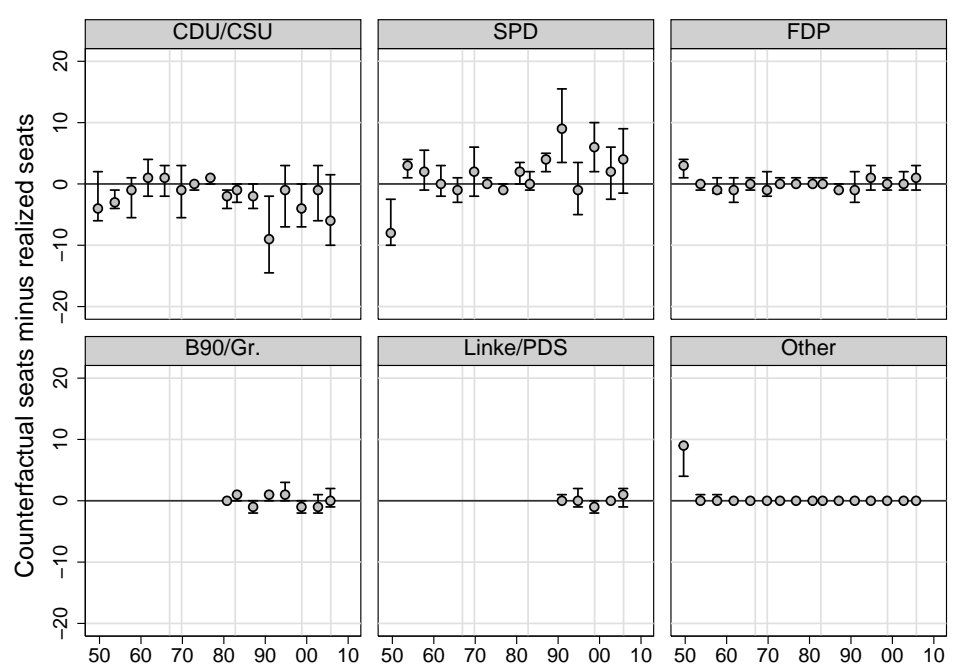

Figure 3: Change in seats in parliament from counterfactual participation of nonvoters $\left(\Delta S_{i}\right)$ with bootstrapped $95 \%$ confidence interval

Do-file: anmpred2.do, grseatshat.do

Republic, in the sense that the party system of the new Federal Republic had not yet consolidated. Several of the old parties of the Weimar Republic_-such as the communist KPD, and the Catholic Zentrum-still played an important role in that election, while the interests of partisans of the Nazis remained orphaned.

The $95 \%$ confidence intervals in figure 3 resulted from the bootstrapped confidence intervals as described in the previous section. Each of the 200 bootstrapped vectors of nonvoters' voting probabilities were entered into the process of generating the number of seats. This procedure resulted in 200 "feasible" distributions of seats for each election, and the plotted confidence intervals show the range of $95 \%$ of these feasible distributions. Overall, the confidence intervals here appear to be much more moderate in size compared to those shown in figure 2, for the most part because even large variations of nonvoters' voting behavior tend to have moderate effects on the distribution of seats, particularly if the number of nonvoters is small.

An overall measure for the disproportionality of the elections due to nonvoters can be designed following Bernhagen and Marsh's use of the Gallagher index of disproportionality (equation (2)). The election-specific results of these calculations are given in figure 4 , which shows that the level of the German parliament's disproportionality due to nonvoters is rather small. The Gallagher index of disproportionality is below 2 for all but the 1949 and 1990 elections, which is about as low as what Bernhagen and Marsh (2007: 552) found for the compulsory voting countries Australia and Belgium. For 1990, disproportionality is around 4, which is similar to the United States; for 1949, it is almost as high as what Bernhagen and Marsh report for Switzerland. 


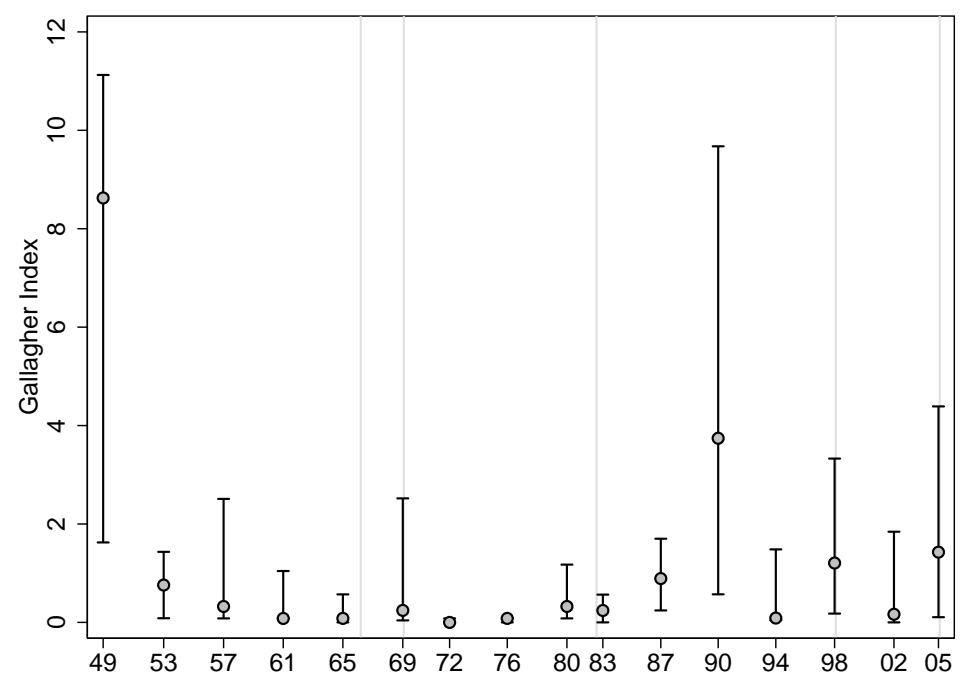

Figure 4: Gallagher index of disproportionality $(\Delta S)$ with bootstrapped $95 \%$ confidence intervals

Do-file: anmpred2.do, grseatshat.do

\subsection{Probability of government change}

In section 2, it was argued that the changeability of government formation depends on the type of the realized government. Of the four government types discussed, Germany has so far predominantly been led by a winner's coalition. The only periods without governments based on a winner's coalition were the first SPD/FDP coalition between 1969 and 1972 under Chancellor Willy Brandt, and the third and fourth SPD/FDP coalitions between 1976 and 1983 under Chancellor Helmut Schmidt. The two other government types described above have not been formed in Germany thus far.

For winner's coalitions, it was proposed that the conditions of government formation change substantially if

- the winner changes hands,

- the realized coalition loses its absolute majority in the parliament, or

- the winning party achieves an absolute majority on its own.

This subsection provides estimates for the probability of each of these situations. These estimates are based on the bootstrapped distribution of seats from the previous subsection. The method used is explained in figure 5 , which shows all 200 bootstrapped counterfactual distributions of seats for the election of 2005. The counterfactual number of seats for each party is shown as a stacked horizontal bar-chart (the bars are very thin). The number of seats for the bourgeois block (the CDU/CSU and the FDP) is depicted with dark shadings, while the seats for the Left parties are represented with bright shadings. A vertical line at the number 308 indicates the number of seats necessary to form the government. 


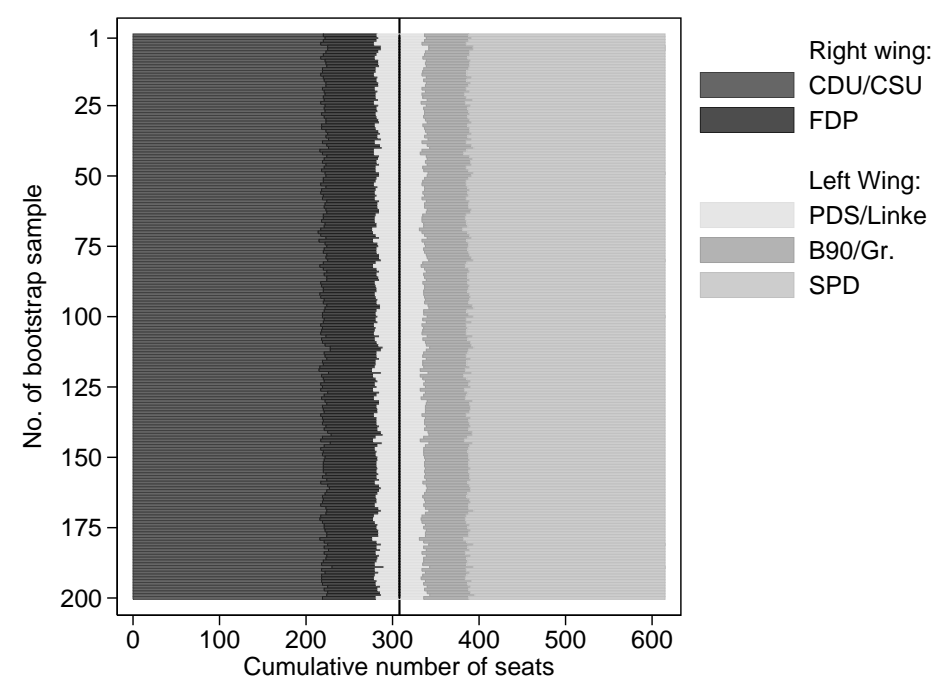

Figure 5: Bootstrapped distribution of seats from the 2005 election

Do-file: anmpred2.do, angovchange.do

The election of 2005 brought 226 seats for the CDU/CSU, 223 seats for the SPD, 61 seats for the FDP, 54 seats for the PDS/Linke, and 51 seats for the Green Party. As a consequence, neither of the two major party blocks - the CDU/CSU and the FDP on the one side, or the SPD and the Greens on the other side-won the 308 seats necessary to elect the chancellor. As the former communist party PDS/Linke was not considered a possible coalition partner by any of the other parties, the only possibility to form a government was through the so-called "grand coalition" between the CDU/CSU and the SPD, which was put into practice on November 22, 2005, by electing Angela Merkel as chancellor.

For the first instance of the bootstrap samples-indicated by the line at the very top of the graph - the estimated number of seats is 222 for the CDU/CSU and 228 for the SPD. Hence, according to this bootstrap sample, the SPD outpaced the real winner, the CDU/CSU, suggesting a government led by the SPD candidate Gerhard Schröder rather than by Angela Merkel. The question then becomes, how likely this case is. One answer to this question which is in line with the theoretical concept of equation (19) points to the proportion of bootstrapped seat distributions where the SPD has more seats than the CDU/CSU. In the case of the 2005 election, this proportion is $90 \%$. Hence, $90 \%$ of the bootstrapped seat distributions are such that the SPD gains more seats than the CDU/CSU, or, in other words, the estimated probability of the winner changing hands due to nonvoters is $90 \%$.

The probabilities of the two other situations can be estimated in a similar fashion. As said, in 2005 the number of seats that was necessary to elect the chancellor was 308, and the grand coalition actually won 449 seats. Looking at the results shown in figure 5, it is fairly obvious that the combined number of seats of the grand coalition is greater than the threshold of 308 in any instance of the bootstrapped samples. Hence, the estimated 


\begin{tabular}{lrrr}
\hline & New winner & Gov. coal. insuff. & Winner suff. alone \\
Election & $\widehat{\operatorname{Pr}}\left(S_{R}^{*}>S_{W}^{*}\right)$ & $\widehat{\operatorname{Pr}}\left(S_{C}^{*}<\frac{1}{2} S\right)$ & $\widehat{\operatorname{Pr}}\left(S_{W^{*}}^{*}>\frac{1}{2} S\right)$ \\
\hline August 14, 1949 & 0 & 0 & 0 \\
September 6, 1953 & 0 & 0 & 0 \\
September 15, 1957 & 0 & 0 & 100 \\
September 17, 1961 & 0 & 0 & 0 \\
September 19, 1965 & 0 & 0 & 0 \\
September 28, 1969 & 0 & 0 & 0 \\
November 19, 1972 & 0 & 0 & 0 \\
October 3, 1976 & 0 & 0 & 0 \\
October 5, 1980 & 0 & 0 & 0 \\
March 6, 1983 & 0 & 0 & 0 \\
January 25, 1987 & 0 & 0 & 0 \\
December 2, 1990 & 0 & 0 & 0 \\
October 16, 1994 & 0 & 2 & 0 \\
September 27, 1998 & 0 & 0 & 0 \\
September 22, 2002 & 10 & 1 & 0 \\
September 18, 2005 & 88 & 0 & 0 \\
\hline
\end{tabular}

Table 2: Estimated probability of government change by election

probability that the realized coalition would not have won enough seats when nonvoters participated in the election is zero 17

Finally, there is the probability that the winning party of the counterfactual election achieves the absolute majority on its own. Here, figure 5 shows that neither the CDU/CSU nor the SPD comes even close to winning the absolute majority of seats throughout. Therefore, the estimated probability that the counterfactual winning party achieves the absolute majority of seats is zero.

To summarize the findings for 2005 , there is a probability of $90 \%$ for another four years of chancellor Gerhard Schröder if nonvoters had participated in that election. However, regardless of nonvoter participation, the predecessor SPD-Bündnis 90/Die Grünen coalition would have been replaced by a grand coalition, as turned out to be the case in reality.

What are the estimates for the probability of government change for the other elections? These figures are given in table 2, which shows in the first column of results the electionspecific estimated probabilities for the winner changing hands. The second column gives the estimated probabilities for the realized coalition losing its majority, and the last column the estimated probabilities for seeing a winner that gains an absolute majority on its own.

Most cells in table 2 are zero, indicating that in postwar Germany the probability of

17 Assuming that the PDS/Linke would not have been considered as a coalition partner for any of the other parties, there is no other coalition besides the realized one that could gain enough seats in any of the bootstrap samples. 
a change in government due to the participation of nonvoters has been negligible. In fact, in only four cases do the results indicate that a different government due to nonvoter participation was even algebraically feasible: the elections of 1957, 1994, 2002, and 2005.

The ability to identify the elections for which government change is impossible is one of the great benefits of the technique proposed here, because it allows one to restrict the discussion of potential alternative governments to the remaining cases. This is important because such counterfactual prognosis requires further qualitative considerations of the specific historical situation at the time of each election. The following discussion exemplifies this process of qualitative analysis by taking up the four outstanding German cases mentioned above.

As discussed, the absence of electors helped Angela Merkel become chancellor in 2005. The next nonzero probability is for the election of 2002, which shows a probability of 9\% that the SPD and its candidate Gerhard Schröder would have been outpaced by the CDU/CSU candidate Edmund Stoiber. It should be noted, however, that in all cases where the counterfactual number of seats for the CDU/CSU is estimated to be higher than that for the SPD, the envisaged bourgeois coalition did not gain enough seats to elect Stoiber as a chancellor. In the (improbable) case that Stoiber would have outpaced Schröder, he would have had to form a coalition with Bündnis 90/Die Grünen in order to become the chancellor; this seems very unlikely given the political debates at the time. Because the SPD-Bündnis 90/Die Grünen coalition retains the absolute majority of seats in any instance where the winner changes hands, it is much more likely that this government would have been formed anyway. It is therefore very unlikely that the participation of nonvoters would have had any effect on government formation in 2002.

For election year 1994, there is a 5\% probability that the realized coalition government of the CDU/CSU and the FDP would not have won enough seats to elect Helmut Kohl as chancellor. However, in all these cases, the formation of an alternative government would have been quite difficult. Neither of the possible SPD-led two-party coalitions-with either the FDP or the Bündnis 90/Die Grünen-would have achieved an absolute majority. In the (improbable) case of Kohl losing his majority through nonvoters' counterfactual participation, he would have been forced to form a grand coalition, or a coalition with Bündnis 90/Die Grünen. Because the latter must be regarded as very unlikely, I conclude that there is a small but nonzero probability that the participation of nonvoters would have led to a grand coalition in 1994.

Finally, table 2 shows a probability of $100 \%$ that the winning party of the counterfactual election would have won the absolute majority of seats in 1957. However, this result originates from the fact that Konrad Adenauer formed a coalition government with the "Deutsche Partei" (DP), even though the CDU/CSU had already won the absolute majority of seats ( 270 of the 497 seats). Although the participation of nonvoters would have likely reduced the number of seats for the CDU/CSU (see figure 3), there is not one single instance among the bootstrapped samples in which the CDU/CSU does not win the absolute majority. In this sense, the conditions for government formation remain unchanged under the counterfactual circumstances. It must therefore be concluded that the realized coalition would have been formed anyway.

All in all, there is little evidence for the possibility of government change due to coun- 
terfactual participation of nonvoters. In most elections, the estimated probability of government change is zero. Of the four cases for which a nonzero probability of government change has been estimated, only the elections of 1994 and 2005 show further qualitative evidence that such a change might have occurred. For 1994 there is a small probability that a grand coalition would have been formed instead of the realized CDU/CSU-FDP coalition, and for 2005 it seems quite likely that the realized grand coalition would have elected Gerhard Schröder as chancellor rather than Angela Merkel.

\section{Summary}

Conventional answers to the question of whether the counterfactual participation of nonvoters would have changed an election result make reference to the change in the division of the vote resulting from adding the putative preferences of nonvoters to those of actual voters (see, e.g., Brunell and DiNardo 2004; Franklin 2004; Lutz and Marsh 2007). Votes, however, are only an input to the determination of the policy-relevant outcomes of an election. In a parliamentary system, the outcome of an election is the distribution of seats in the parliament and the bargaining conditions for the formation of a government. To understand the impact of nonvoters on this outcome, an explicit model of a multistage process (Grofman et al. 1999: 364ff) is required.

This article has provided a detailed examination of the steps that are necessary to estimate the effects of nonvoters on the distribution of seats and on the probability of government change in a parliamentary system. To estimate the effects on the distribution of seats, two estimates and a set of institutional and election-specific observations are required. The estimates are the counterfactual voting behavior of nonvoters, which could be inferred from standard theories of voting behavior, and the maximum valid turnout. The institutional observations are the particularities of the apportionment method, the barring clause, and the size of the parliament. Finally, the election-specific figures are the absolute numbers of valid votes for each party at the real election, and the size of the electorate. After all these quantities are obtained, the counterfactual distribution of seats can be estimated by applying the respective formulas provided in subsection 2.2 of this article.

The estimation of the probability of government change due to nonvoters' participation requires the estimation of the counterfactual distribution of seats. Additionally, one has to estimate the uncertainty of that estimation and to classify the realized government into one of four different government types: single-party government, winner's coalition, consent coalition, or minority government. The formulas given in subsection 2.2 then allow one to quantify the probability of a change in the conditions of government formation, which in turn allows one to identify those elections in which the formation of a different government could be quite likely, or at least possible.

The general model outlined in section 2 of this article has been applied in section 3 to German national elections from 1949 to 2005. The empirical findings of that application show that Germany's Social Democratic Party (SPD) would have gained most from the counterfactual participation of nonvoters. However, the application also shows that the level of disproportionality induced by nonvoting is not a constant feature of the German 
system. Disproportionality is fairly low for most German elections, but can become quite substantial under specific conditions. So far, 1949 and 1990 have been the German elections with the highest level of disproportionality. Both elections have in common that they are the first elections after a breakdown of an entire political system-the Nazi regime for 1949 and the communist regime for 1990.

In terms of the probability of government change, the empirical results show that so far the counterfactual participation of nonvoters would most likely not have had a big influence on government formation in Germany. Of all national elections since 1949, only the elections of 1994 and 2005 show evidence that such a change could have happened. For 1994, there is a small probability that a grand coalition would have been formed instead of the realized CDU/CSU-FDP coalition, and for 2005 it seems quite likely that the realized grand coalition would have elected Gerhard Schröder as chancellor rather than Angela Merkel.

The fact that both the representation gap and the probability of government change vary from election to election gives rise to the question of what lies behind this variation. There are several possible explanations. Some of the more obvious ones are described by Kohler and Rose (2008): the proportion of nonvoters, the distribution of votes in the realized election results, the number of parties participating in the election, the differences in political preferences between voters and nonvoters, and the coalition preferences of parties. However, it was not the goal of this article to deal with this question. An exploration of this question is postponed to further work, though some initial steps have already been taken: a data set with the required information for all German elections on the state level has been created, a program has been written for applying the apportionment methods for arbitrary election results; and a generalized program for estimating the effects of nonvoter participation on the election outcome is under development.

\section{References}

Berelson, B. R., Lazarsfeld, P. F., McPhee, W. N. (1954): Voting. A Study of Opinion Formation in a Presidential Campaign. Chicago: University of Chicago Press.

Bernhagen, P., Marsh, M. (2007): The partisan effects of low turnout: Analyzing vote abstention as a missing data problem. Electoral Studies, 26, 548-560.

Brunell, T. L., DiNardo, J. (2004): A Propensity Score Reweighting Approach to Estimating the Partisan Effects of Full Turnout in American Presidential Elections. Political Analysis, 12, 28-45.

Campbell, A., Converse, P. E., Miller, W. E., Stokes, D. E. (1960): The American Voter. New York u. London: Wiley.

Campbell, A., Gurin, G., Miller, W. E. (1954): The Voter Decides. Evanston: Row, Peterson.

Downs, A. (1957): An Economic Theory of Democracy. New York: Harper \& Brothers.

Efron, B., Tibshirani, R. J. (1993): An Introduction to the Bootstrap. New York: Chapman and Hall.

Fiorina, M. P. (1981): Retrospective Voting in American National Election. New Haven, Conn.: Yale University Press. 
Fisher, S. D. (2007): (Change in) turnout and (change in) the left share of the vote. Electoral Studies, 26(3), 598-611.

Franklin, M. N. (2004): Voter Turnout and the Dynamics of Electoral Competition in Established Democracies since 1945. New York: Cambridge University Press.

Gallagher, M. (1991): Proportionality, disproportionality and electoral systems. Electoral Studies, 10, 33-51.

Grofman, B., Owen, G., Collete, C. (1999): Rethinking the Partisan Effects of Higher Turnout: So What's the Question? Public Choice, 99, 357-376.

Huckfeldt, R. R., Sprague, J. (1995): Citizens, Politics, and Social Communication. Information and Influence in an Election Campaign. Cambridge: Cambridge University Press.

Kohler, U., Rose, R. (2008): Election Outcomes and maximizing turnout: Modelling the effect, wZB Discussion Paper SP I 2008-203.

Laver, M., Shepsle, K. (1996): Making and Breaking Governments. New York: Cambridge University Press.

Lazarsfeld, P. F., Berelson, B., Gaudet, H. (1948): The People's Choice. How Voter Makes up his Mind in a Presidential Campaign. New York: Columbia University Press.

Linz, J. (1967): Cleavage and Consensus in West German Politics: The Early Fifties. In Party Systems and Voter Alignments: Cross-National Perspective, New York: Free Press, pp. 283321.

Lipset, S. M. (1960): Political Man. New York: Doubleday.

Lipset, S. M., Rokkan, S. (1967): Cleavage Structures, Party Systems and Voter Alignments: an Introduction. In Party Systems and Voter Alignments: Cross-National Perspective, New York: Free Press, pp. 1-64.

Long, S. J. (1997): Regression Models for Categorical and Limited Dependent Variables. Thousand Oaks: Sage.

Lutz, G., Marsh, M. (2007): Introduction: Consequences of Low Turnout. Electoral Studies, 26, 539-547.

Mackerras, M., McAllister, I. (1999): Compulsory voting, party stability and electoral advantage in Australia. Electoral Studies, 18, 217-233.

Miller, W. E., Shanks, M. (1996): The New American Voter. Cambridge u. London: Harvard University Press.

Oppenhuis, E. V. (1995): Voting Behaviour in Europe: A Comparative Analysis of Electoral Participation and Party Choice. Amsterdam: Het Spinhuis.

Pappi, F. U. (1976): Sozialstruktur und politische Konflikte in der Bundesrepublik Deutschland. Individual- und Kontextanalyse der Wahlentscheidung. Habil. Köln: Universität Köln.

Pappi, F. U. (1986): Das Wahlverhalten sozialer Gruppen bei Bundestagswahlen im Zeitvergleich. In Kaase, M., Klingemann, H.-D., eds., Wahlen und politischer Prozeß. Analysen aus Anlaß der Bundestagswahl 1983, Opladen: Westdeutscher Verlag, pp. 369-384.

Pappi, F. U. (2002): Die politisierte Sozialstruktur heute: Historische Reminiszenz oder aktuelles Erklärungspotential? In Brettschneider, F., Deth, J. v., Roller, E., eds., Das Ende der politisierten Sozialstruktur, Opladen: Leske und Budrich, pp. 24-46.

Pappi, F. U., Shikano, S. (2002): Die politisierte Sozialstruktur als mittelfristig stabile Basis einer deutschen Normalwahl. Kölner Zeitschrift für Soziologie und Sozialpsychologie, 54(3), 444-475. 
Powell, B. (1986): American Voter Turnout in Comparative Perspective. American Political Science Review, 80(1), 17-43.

Powell, B. (2000): Elections as Instruments of Democracy: Majoritarian and Proportional Visions. New Haven: Yale University Press.

Statistisches Bundesamt, ed. (2005): Wahl zum 16. deutschen Bundestag am 18. September 2005. Heft 1: Ergebnisse und Vergleichszahlen früherer Bundestags- Europa- und Landtagswahlen sowie Strukturdaten für die Bundestagswahlkreise. Stuttgart: Metzler-Poeschel.

Steinbrecher, M., Huber, S., Rattinger, H. (2007): Turnout in Germany. Citizen Participation in State, Federal, and European Elections since 1979. Baden-Baden: Nomos. 


\section{Appendix}

\begin{tabular}{|c|c|c|c|c|}
\hline ZA-Nr. & Study Name & Sampling & Fieldwork Period & Obs. \\
\hline \multicolumn{5}{|c|}{ Election day 14 August 1949} \\
\hline 2324 & Wahlstudie 1949 & Quota & 01Feb49-28Mar49 & 1000 \\
\hline 2361 & Situation nach der Btw 1949 & uota & 15Aug49-31Aug49 & 1885 \\
\hline \multicolumn{5}{|c|}{ Election day 6 September 1953} \\
\hline 0145 & $\begin{array}{l}\text { Wahlstudie } 1953 \text { (Bun- } \\
\text { desstudie) }\end{array}$ & Random & 01Jul53 -31Aug53 & 2805 \\
\hline \multicolumn{5}{|c|}{ Election day 15 September 1957} \\
\hline 3272-III & Wahlstudie 1957 & Quota & 01Sep57-14Sep57 & 1816 \\
\hline \multicolumn{5}{|c|}{ Election day 17 September 1961} \\
\hline 0056 & $\begin{array}{l}\text { Wahlstudie } 1961 \text { (Kölner } \\
\text { Wahlstudie) }\end{array}$ & Random & 01Sep61 -16Sep61 & 1228 \\
\hline 0057 & $\begin{array}{l}\text { Wahlstudie } 1961 \text { (Kölner } \\
\text { Wahlstudie) }\end{array}$ & Random & 01Nov61-31Dec61 & 1405 \\
\hline \multicolumn{5}{|c|}{ Election day 19 September 1965} \\
\hline 0314 & $\begin{array}{l}\text { Wahlstudie } \\
\text { (Nachunters.) }\end{array}$ & Random & 01 Oct65 -31Oct65 & 1141 \\
\hline 0556 & $\begin{array}{l}\text { Wahlstudie } 1965 \text { (Vorunter- } \\
\text { suchung) }\end{array}$ & Random & 01Sep65-14Sep65 & 1302 \\
\hline \multicolumn{5}{|c|}{ Election day 28 September 1969} \\
\hline 0426-II & Wahlstudie 1969 (Panel) & Random & 17Oct69-09Nov69 & 758 \\
\hline 0525-II & $\begin{array}{l}\text { Wahlstudie } 1969 \text { (Politik in } \\
\text { der BRD) }\end{array}$ & Random & 01Sep69-27 & 855 \\
\hline \multicolumn{5}{|c|}{ Election day 19 November 1972} \\
\hline 0635 & Wahlstudie 1972 (Panel) & Random & 01Dec72-31Dec72 & 1221 \\
\hline \multicolumn{5}{|c|}{ Election day 3 October 1976} \\
\hline 0823 & Wahlstudie 1976 (Panel) & Random & 26 Oct76-19Nov76 & 1195 \\
\hline \multicolumn{5}{|c|}{ Election day 5 October 1980} \\
\hline 1053-IX & $\begin{array}{l}\text { Politbarometer } \\
\text { (September) }\end{array}$ & Random & 01Sep80-30Sep80 & 1409 \\
\hline $1053-X$ & $\begin{array}{l}\text { Politbarometer } 1980 \text { (Octo- } \\
\text { ber) }\end{array}$ & $\mathrm{m}$ & ct80 & 999 \\
\hline \multicolumn{5}{|c|}{ Election day 6 March 1983} \\
\hline 1276 & $\begin{array}{l}\text { Wahlstudie } 1983 \text { (Panel- } \\
\text { studie) }\end{array}$ & Random & 07Mar83-31Mar83 & 1014 \\
\hline 1281 & $\begin{array}{l}\text { Politbarometer } \\
\text { (March) }\end{array}$ & Random & 07Mar83-31Mar83 & 1032 \\
\hline \multicolumn{5}{|c|}{ Election day 25 January 1987} \\
\hline 1536-II & $\begin{array}{l}\text { Politbarometer } 1987 \text { (Febru- } \\
\text { ary) }\end{array}$ & Random & 01Feb87-28Feb87 & 1986 \\
\hline 1537-III & $\begin{array}{l}\text { Wahlstudie } 1987 \text { (Panel- } \\
\text { studie) }\end{array}$ & Random & 06Feb87-23Feb87 & 1311 \\
\hline \multicolumn{5}{|c|}{ Election day 2 December 1990} \\
\hline 1920-XI & $\begin{array}{l}\text { Politbarometer } \\
\text { (November) }\end{array}$ & RLD & 01Nov90-30Nov90 & 939 \\
\hline 1920-XII & $\begin{array}{l}\text { Politbarometer } 1990 \text { (De- } \\
\text { cember) }\end{array}$ & RLD & 03Dec90-30Dec 90 & 1035 \\
\hline 1987-XII & 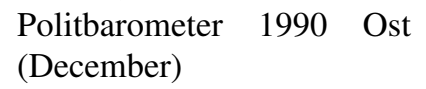 & Random & 03Dec90-30Dec90 & 1112 \\
\hline
\end{tabular}


Continued from previous page

\begin{tabular}{|c|c|c|c|c|}
\hline ZA-Nr. & Study Name & Sampling & Fieldwork Period & Obs. \\
\hline \multicolumn{5}{|c|}{ Election day 16 October 1994} \\
\hline 2546-IX & $\begin{array}{l}\text { Politbarometer } \\
\text { (September) }\end{array}$ & RLD & 01 Oct $94-15$ Oct 94 & 1116 \\
\hline 2559-IX & $\begin{array}{l}\text { Wahlstudie } 1994 \quad \text { (Polit- } \\
\text { barom. Ost) }\end{array}$ & Random & $010 c t 94-15$ Oct 94 & 906 \\
\hline 2600 & Vorw.-stud. 1994 & Random & 01 Oct $94-15$ Oct 94 & 2258 \\
\hline 2601 & Nachw.-stud. 1994 & Random & 17Oct94-09Nov94 & 2033 \\
\hline $3065-\mathrm{I}$ & $\begin{array}{l}\text { Polit. Einst., polit. Part. u. } \\
\text { Wählerverh. i. verein. Dtld } \\
1994\end{array}$ & Random & 12Sep94-14Oct94 & 1844 \\
\hline 3065-II & $\begin{array}{l}\text { Polit. Einst., polit. Part. u. } \\
\text { Wählerverh. i. verein. Dtld } \\
1994\end{array}$ & Random & 24Oct94-01Dec94 & 1783 \\
\hline \multicolumn{5}{|c|}{ Election day 27 September 1998} \\
\hline 3066-I & $\begin{array}{l}\text { Polit. Einst., polit. Part. u. } \\
\text { Wählerverh. i. verein. Dtld } \\
1994\end{array}$ & Random & 26Aug98-26Sep98 & 1506 \\
\hline 3066-II & $\begin{array}{l}\text { Polit. Einst., polit. Part. u. } \\
\text { Wählerverh. i. verein. Dtld } \\
1994\end{array}$ & Random & 08Oct98-21Nov98 & 1417 \\
\hline 3073 & $\begin{array}{l}\text { Dt. Nat. Wahlstudie - } \\
\text { Nachw.-stud. } 1998 \text { (Dt. } \\
\text { CSES-Studie) }\end{array}$ & Random & 28Sep98-17Oct98 & 2011 \\
\hline 3160-IX & $\begin{array}{l}\text { Politbarometer } 1998 \text { (Sep- } \\
\text { 38KW) }\end{array}$ & RLD & 14Sep98-20Sep98 & 1153 \\
\hline $3160-X$ & $\begin{array}{l}\text { Politbarometer } 1998 \text { (Octo- } \\
\text { ber) }\end{array}$ & RLD & 01 Oct $98-30$ Oct 98 & 1148 \\
\hline 3160-XI & $\begin{array}{l}\text { Politbarometer } \\
\text { (November) }\end{array}$ & RLD & 01Nov98-30Nov98 & 1204 \\
\hline 3160-XII & $\begin{array}{l}\text { Politbarometer } 1998 \text { (De- } \\
\text { cember) }\end{array}$ & RLD & 01Dec98-30Dec98 & 1172 \\
\hline \multicolumn{5}{|c|}{ Election day 22 September 2002} \\
\hline 3861-I & $\begin{array}{l}\text { Political Attitudes, Political } \\
\text { Participation and Voter (Vor- } \\
\text { wahl) }\end{array}$ & Random & 12Aug02-21Sep02 & 1569 \\
\hline 3861-II & $\begin{array}{l}\text { Political Attitudes, Politi- } \\
\text { cal Participation and Voter } \\
\text { (Nachwahl) }\end{array}$ & Random & 01Oct02-08Nov02 & 1545 \\
\hline \multicolumn{5}{|c|}{ Election day 18 September 2005} \\
\hline WZB & $\begin{array}{l}\text { Testmodul deutsche CSES } \\
\text { III }\end{array}$ & RLD & 01 Oct05-30Oct05 & 2017 \\
\hline
\end{tabular}


Books published by members of the research unit Inequality and Social Integration

(only available from commercial or institutional retailers)

\section{9}

Alber, Jens, Neil Gilbert (eds.)

United in Diversity? Comparing Social Models in Europe and America

Oxford/New York: Oxford University Press 2009, 464 pages

Blome, Agnes, Wolfgang Keck, Jens Alber Family and the Welfare State in Europe. Intergenerational Relations in Ageing Societies

Cheltenham, UK/Northhampton: Edward

Elgar 2009, 342 pages

\section{8}

Alber, Jens, Tony Fahey, Chiara Saraceno (eds.)

Handbook of Quality of Life in the

Enlarged European Union

London/New York: Routledge 2008, 430 pages

Blome, Agnes, Wolfgang Keck, Jens Alber Generationenbeziehungen im

Wohlfahrtsstaat. Lebensbedingungen und Einstellungen von Altersgruppen im internationalen Vergleich

Wiesbaden: VS-Verlag 2008, 419 pages

\section{7}

Scherer, Stefani, Reinhard Pollak, Gunnar Otte, Markus Gangl (eds.)

From Origin to Destination. Trends and Mechanisms in Social Stratification Research

Frankfurt a.M.: Campus Verlag 2007, 323 pages
Zimmer, Annette, Eckhard Priller Gemeinnützige Organisationen im gesellschaftlichen Wandel. Ergebnisse der Dritte-Sektor-Forschung, 2. Auflage Wiesbaden: VS Verlag für

Sozialwissenschaften 2007, 237 pages

\section{6}

Alber, Jens, Wolfgang Merkel (eds.)

Europas Osterweiterung: Das Ende der Vertiefung?

Berlin: edition sigma 2006, 429 pages

Böhnke, Petra

Am Rande der Gesellschaft - Risiken sozialer Ausgrenzung

Opladen: Verlag Barbara Budrich 2006, 249 pages

Kohler, Ulrich, Frauke Kreuter Datenanalyse mit Stata. Allgemeine Konzepte der Datenanalyse und ihre praktische Durchführung, 2. vollständig überarbeitete und ergänzte Auflage München/Wien: Oldenbourg Verlag 2006, 410 pages

\section{5}

Birkhölzer, Karl, Ansgar Klein, Eckhard Priller, Annette Zimmer (eds.)

Dritter Sektor/Drittes System - Theorie, Funktionswandel und zivilgesellschaftliche Perspektiven

Wiesbaden: VS Verlag für

Sozialwissenschaften 2005, 315 pages

Böhnke, Petra

First European Quality of Life Survey:

Life satisfaction, happiness and sense of belonging

European Foundation for the Improvement of Living and Working Conditions, Luxembourg: Office for Official Publications of the European Communities 2005, 100 pages

Kohler, Ulrich, Frauke Kreuter

Data Analysis Using Stata

College Station: Stata Press 2005, 378 pages 


\section{4}

Alber, Jens, Ulrich Kohler

Health and care in an enlarged Europe

European Foundation for the Improvement of Living and Working Conditions,

Luxembourg: Office for Official

Publications of the European Communities 2004, 84 pages

Alber, Jens, Tony Fahey

Perceptions of living conditions in an enlarged Europe

European Foundation for the Improvement of Living and Working Conditions,

Luxembourg: Office for Official

Publications of the European Communities 2004, 59 pages

Alber, Jens, Jan Delhey, Wolfgang Keck, Ricarda Nauenburg et al.

Quality of life in Europe

European Foundation for the Improvement of Living and Working Conditions,

Luxembourg: Office for Official

Publications of the European Communities 2004, 112 pages

Böhnke, Petra

Perceptions of social integration and exclusion in an enlarged Europe

European Foundation for the Improvement of Living and Working Conditions,

Luxembourg: Office for Official

Publications of the European Communities

2004, 62 pages

Delhey, Jan

Life satisfaction in an enlarged Europe

European Foundation for the Improvement of Living and Working Conditions,

Luxembourg: Office for Official

Publications of the European Communities

2004, 76 pages

Statistisches Bundesamt (ed.), in

Zusammenarbeit mit dem

Wissenschaftszentrum Berlin für Sozialforschung und dem Zentrum für Umfragen, Methoden und Analysen,

Mannheim (ZUMA)

Datenreport 2004. Zahlen und Fakten

über die Bundesrepublik Deutschland.

Schriftenreihe der Bundeszentrale für politische Bildung, Band 450, Bonn 2004.

Teil II „Objektive Lebensbedingungen und subjektives Wohlbefinden im vereinten
Deutschland“, hrsg. von Roland Habich, Heinz-Herbert Noll, pp. 449-679.

Zimmer, Annette, Eckhard Priller (eds.) with the assistance of Matthias Freise

Future of Civil Society, Making Central European Nonprofit-Organizations Work

VS Verlag für Sozialwissenschaften: Wiesbaden 2004, 736 pages

Zimmer, Annette, Eckhard Priller, unter Mitarbeit von Lilian Schwab und Thorsten Hallmann

Gemeinnützige Organisationen im gesellschaftlichen Wandel. Ergebnisse der Dritte-Sektor-Forschung

Wiesbaden: VS Verlag für

Sozialwissenschaften 2004, 237 pages 


\section{Discussion Papers}

of the research unit Inequality and Social Integration

(available via Informations- und

Kommunikationsreferat, Wissenschaftszentrum Berlin für Sozialforschung, Reichpietsufer 50, 10785 Berlin, email: presse@wzb.eu; download at htttp://www.wzb.eu/publikation/)

\section{9}

Jens Alber, Florian Fliegner, Torben Nerlich Charakteristika prämierter Forschung in der deutschsprachigen Sozialwissenschaft. Eine Analyse der mit dem Preis der Fritz Thyssen Stiftung ausgezeichneten sozialwissenschaftlichen Aufsätze 1981-2006

Order No.: SP | $2009-201$

\section{Yan Hao}

Poverty and Exclusion in Urban China Order No.: SP I $2009-202$

\section{Jens Alber}

What the European and American welfare states have in common and where they differ - Facts and fiction in comparisons of the European Social Model and the United States Order No.: SP I $2009-203$

Dietllind Stolle, Marc Hooghe Shifting Inequalities? Pattern of Exclusion and Inclusion in Emerging Forms of Political Participation Order No.: SP I $2009-204$

Petra Böhnke Abwärtsmobilität und ihre Folgen: Die Entwicklung von Wohlbefinden und Partizipation nach Verarmung Order No.: SP I $2009-205$

\section{Ulrich Kohler}

Estimating the Potential Impact of Nonvoters on Outcomes of Parliamentary Elections in Proportional Systems with an Application to German National Elections from 1949 to 2005 Order No.: SP I $2009-206$

\section{8}

Petra Böhnke, Ulrich Kohler Well-being and Inequality Order No.: SP I 2008 - 201

Jens Alber, Ulrich Kohler The inequality of electoral participation in Europe and America and the politically integrative functions of the welfare state

Order No.: SP | $2008-202$

Ulrich Kohler, Richard Rose

Election Outcomes and Maximizing Turnout: Modelling the Effect

Order No.: SP I $2008-203$

Thomas A. DiPrete, Andrew Gelman, Julien Teitler, Tian Zheng, Tyler McCormick

Segregation in Social Networks based on Acquaintanceship and Trust

Order No.: SP | $2008-204$

Karen M. Anderson

The Politics of Multipillar Pension

Restructuring in Denmark, the Netherlands and Switzerland Order No.: SP I 2008 - 205

\section{7}

Richard Rose

Evaluating Democratic Governance: A Bottom Up Approach to European Union Enlargement

Order No.: SP | 2007 - 201

Petra Böhnke

Poverty and Social Integration in the

Enlarged Europe

Order No.: SP | 2007 - 202

Petra Böhnke

Policy or Privacy - What Matters Most for Individual Well-Being?

Order No.: SP | 2007 - 203

Marco Albertini, Chiara Saraceno Contact between adult children and their divorced parents: Italy in a comparative perspective Order No.: SP I 2007 - 204 
Jens Alber

Where Turkey stands in Europe and why it should be admitted to the EU

Order No.: SP I 2007 - 205

\section{6}

\section{Stein Ringen}

Reflections on Inequality and Equality

Order No.: SP | 2006 - 201

\section{5}

Ricarda Nauenburg

Globalisierung und rechtspopulistische Wahlerfolge

Order No.: SP | $2005-201$

Eckhard Priller, Jana Sommerfeld Wer spendet in Deutschland? Eine sozialstrukturelle Analyse Order No.: SP | 2005 - 202

Jan Delhey

A trade-off between enlargement and integration? An analysis of trust between EU nationalities

Order No.: SP I $2005-203$

Jan Delhey, Urlich Kohler

From Nationally Bounded to Pan-

European Inequalities? On the

Importance of Foreign Countries as

Reference Groups

Order No.: SP I 2005 - 204

\section{4}

\section{Jan Delhey}

European Social Integration.

From convergence of countries to transnational relations between people Order No.: SP | $2004-201$

Jan Delhey, Kenneth Newton Social Trust: Global Pattern or Nordic Exceptionalism?

Order No.: SP | $2004-202$

\section{Ulrich Kohler}

Empirische Untersuchung zweier Individualisierungshypothesen mit Querschnittsdaten aus 28 Ländern Order No.: SP | $2004-203$
2003

Harold L. Wilensky

Postindustrialism and

Postmaterialism? A Critical View of the

"New Economy", the "Information

Age", the "High Tech Society", and All

That

Order No.: SP I $2003-201$

Wilhelm Hinrichs

Ausländische Bevölkerungsgruppen in Deutschland. Integrationschancen 1985 und 2000

Order No.: SP | $2003-202$ 